\title{
Avaliação biométrica dos cascos de equinos do Batalhão da Polícia Militar de Minas Gerais na cidade de Itajubá
}

Centro Universitário de Itajubá (FEPI), Itajubá, MG, Brasil

*Autor correspondente

e-mail: nataliasantana20@live.com

\section{Resumo}

Durante a sua evolução os membros dos equinos sofreram adaptações para locomoção em altas velocidades, incluindo a simplificação da região distal a um único dígito, possuindo três falanges proximal, média e distal. O casco é considerado uma modificação cornificada da epiderm, no qual se localiza uma camada vascular responsável por nutrir todas as estruturas do mesmo. Podemos perceber que entre as anormalidades de equilíbrio podal, destacam-se o desnivelamento dorso-palmar e médio-lateral, contração dos talões e ranilha, diferença entre o ângulo da pinça dos cascos contralaterais e tamanho do casco em relação ao peso do animal. Dentre as raças nacionais destaca-se o Brasileiro de Hipismo que, mesmo possuindo um rebanho menor quando comparado com outras raças nacionais, apresenta uma participação considerável nas competições olímpicas nacionais e internacionais. Este trabalho teve como objetivo realizar a biometria dos cascos dos equinos da raça Brasileira de Hipismo da Polícia Militar de Minas Gerais, situada na cidade de Itajubá. Para o desenvolvimento foi realizado a avaliação biométrica dos cascos com os animais realizando, assim, a mensuração das seguintes estruturas anatômicas: ângulo e comprimento da pinça, comprimento e largura da sola, comprimento e largura da ranilha, distância do ápice da ranilha à parede medial/lateral do casco na superfície solear, altura da muralha medial/lateral, circunferência da superfície de contato do casco. Os animais se encontravam em estação e com o auxílio de um podogoniômetro foi realizada a mensuração do ângulo da pinça; o comprimento da pinça na região dorsal da muralha do casco foi determinado com auxílio de um paquímetro, considerando-se a medida desde a superfície solear até a região da faixa coronária; o comprimento e a largura de sola foram obtidos medindo-se a distância entre a base do casco e a pinça e entre as laterais do casco na superfície solear, respectivamente. 0 comprimento da ranilha compreende a distância entre sua base na altura do bulbo do casco até o seu ápice, enquanto a sua largura compreende a medida da base da ranilha na altura do bulbo do casco. A distância do ápice 
da ranilha à parede medial/lateral é obtida do ápice da ranilha à borda da muralha, na superfície solear. Foram encontrados valores médios de $13,1 \mathrm{~cm}$ para comprimento de sola; $12,7 \mathrm{~cm}$ para largura de sola; 8,8 cm pra comprimento de ranilha; 5,1 cm para largura de ranilha; $10,1 \mathrm{~cm}$ para comprimento de pinça; 8,3 para altura de quarto medial de muralha e 8,2 cm para o quarto lateral; 4,3 cm e 3,9 para alturas de talão lateral e medial, respectivamente; $37,7 \mathrm{~cm}$ para circunferência de casco e 48,71ำ para ângulo de casco. Os resultados observados diferem quando comparados aos da literatura consultada: comprimento de sola (> $0,58 \mathrm{~cm})$, largura de sola $(>1,39 \mathrm{~cm})$, comprimento de ranilha $(>0,61 \mathrm{~cm})$, largura da ranilha $(>0,54 \mathrm{~cm})$, comprimento de pinça $(>1,37 \mathrm{~cm})$, comprimento de quartela medial $(>1,6 \mathrm{~cm})$, comprimento de quartela lateral $(>1,2 \mathrm{~cm})$, comprimento de diâmetro de casco $(>4,65 \mathrm{~cm})$, altura de talão medial $(>0,29 \mathrm{~cm})$, altura de talão lateral $(<0,1 \mathrm{~cm})$, circunferência de casco $(>4,65 \mathrm{~cm})$ e ângulo de casco $(<0,71 \mathrm{~cm})$. Os principais fatores que alteram os valores biométricos podem ser raça, manejo nutricional, casqueamento dos animais e estado clínico. A principal razão desta diferença se dá pelo intervalo de casqueamento adotado ser maior do que o indicado pela literatura, podendo levar ao desbalanceamento dos mesmos. Conclui-se que os equinos da Polícia Militar de Minas Gerais, situada na cidade de Itajubá, apresentaram valores biométricos diferentes aos citados pela literatura consultadas e que o casqueamento e ferrageamento dos animais deve seguir uma frequência adequada a fim de se evitar quaisquer problemas de locomoção como, por exemplo, caludicação.

Palavras-chave: Biometria. Casco. Claudicação.

Agradecimentos: ao Centro Universitário de Itajubá - FEPI pela bolsa concedida e à Fundação de Amparo à Pesquisa de Minas Gerais. 